\title{
CORPORATE GOVERNANCE IN EXPORT-ORIENTED SMALL AND MEDIUM-SIZED ENTERPRISES IN THE MANUFACTURING INDUSTRY
}

\author{
Nataša Kecman, \\ Jelena Vasić \\ Chamber of Commerce and \\ Industry of Serbia, \\ Belgrade, Serbia
}

\begin{abstract}
:
According to the Statistical Office of the Republic of Serbia, the number of registered small and medium-sized enterprises accounted for only 3.6 percent of the total number of registered micro, small, medium-sized enterprises and entrepreneurs (MSME) ${ }^{1}$ in 2015. Small and medium enterprises comprised 51.7 percent of MSME employees, while the income from exports accounted for as much as 77 percent of export revenues of the MSME sector (export activities were registred in 36 percent of the total number of small enterprises and 52.5 percent of the total number of medium-sized enterprises). Considering the important role of these companies in the manufacturing industry in the domestic economy, this paper is focused on testing basic business compliance with key areas of corporate governance in the group of small and medium-sized enterprises with the highest credibility in business and high credit worthiness. The focus of the research is on the role of owners, management and supervision over business, as well as on the transparency of the companies' operations and commitment to the basic principles of corporate governance. The paper demonstrates an analytical presentation of the business according to the technology intensity, which points to the leading areas of the manufacturing industry with the highest potential for growth in the following period.
\end{abstract}

Keywords:

corporate governance, MSME sector, technology intensity, the manufacturing industry.
Correspondence:

Nataša Kecman

e-mail:

n_kecman@yahoo.com

\section{INTRODUCTION}

With the Economic Reforms Programme of the Government of the Republic of Serbia for the period 2017-2019, and within the indicators for monitoring the development of the industry sectors, an average annual growth rate of export of $5.0 \%$ was foreseen for the manufacturing industry in the period 2015-2018. ${ }^{2}$ In order to achieve the objectives identified by this Programme, in addition to the usual factors that determine the dynamics of exports, it is also essential to look at the operations of management in economic entities since entering foreign markets requires efficient management organization, which has to have all the necessary information in a timely manner. This is especially important in the segment of small and medium-sized enterprises, which all have a growing importance in the Serbian economy.

1 The MSME sector includes micro, small, medium enterprises and entrepreneurs. According to the Eurostat methodology and Recommendation of the European Commission in 2003, the following classification of entities engaged in an economic activity, according to the size within the MSME sector was made according to the number of employees: micro enterprises (up to 9 employees), small enterprises (number of employees from 10 to 49) and medium-sized enterprises (number of employees from 50 to 249). According to the methodology used in MSME Report of Serbian Ministry of Economy, entrepreneurs are considered micro enterprises. Out of the total number of enterprises and entrepreneurs in 2015 (325,094, including also large enterprises), the ones that operated were 9,531 small enterprises (out of which 3,447 exporters) and 2,182 medium enterprises (out of which 1,145 were exporters), that employed 190,963 and 223,505 employees, respectively.

2 Government of Republic of Serbia (2017). Economic Reforms Programme for the period 20172019, p. 112. 
The analysis of the Business Registers Agency, according to the sizes of the companies ${ }^{3}$, indicated that the achieved net result of medium-sized enterprises was 73.7\% higher in 2016 than in 2015, and the realized net result of small enterprises in 2016 increased by $66.0 \%$ compared to the preceding year.

According to the Statistical Office of the Republic of Serbia ${ }^{4}$, small and medium-sized enterprises in the manufacturing industry in Serbia are more numerous than their participation in the total economy: in 2015, every fifth company in the manufacturing industry was classified as small or medium-sized. Small and medium-sized enterprises in the manufacturing sector employ $44 \%$ of the total number of employees in the same sector, they generate $38 \%$ of the sector's turnover and create $40 \%$ of the added value of it. Having in mind the importance of the SME management process, the paper analyzes the implementation of the principles of corporate governance in four export oriented companies, selected according to the technology intensity.

\section{LITERATURE REVIEW}

The term "corporate governance" denotes the mechanism that manages and controls business activities in companies. Good corporate governance is one of the basic requirements for the efficiency of companies' business operations, their reputation and long-term endurance on the market. Shleifer i Vishny ${ }^{5}$ defined the corporate governance as a number of methods that ensure the investors' safe returns on investments in companies, while wondering at the same time how investors that are investing in funds could be confident that they would make the returns on investments. French Nobel laureate Tirol $^{6}$ believes that companies have much broader social liability in market value incrementation and in realization of the expectations of all interested stakeholders ${ }^{7}$, considering that during the procedure of the organization of corporate governance system one must consider the impact of corporate governance systems on all stakeholders (not only on the owners and creditors). This has expanded the focus from the shareholders to other interested parties in the business of the corporation, thus defining the corporate governance as "the structure of institutions that forces and directs the management to internalize the wealth of stakeholders". The most acclaimed definition of corporate governance was proposed by the Organization for Economic

3 The Business Registers Agency. (2017). Report on Economy Performance in Republic of Serbia in 2016.p. 25.

4 Statistical Office of the Republic of Serbia, http://www.stat.gov.rs

5 Shileifer A., Vishny R. W. (1996). A Survey of Corporate Governance.National Bureau of Economic Research, Working Paper 5554 p.2.

6 Tirole J. (2001). Corporate Governance. Econometrica 69 (1): 1-35

7 The term stakeholder stands for all the subjects interested in the future of the companies business considering their interests (investors, lenders, creditors, financial intermediaries, employees, consumers, management, suppliers, governments and others interested parties. In the translation of the OECD's paper 'The Basic Principles of Corporate Governance", the term stakeholder is translated as "interested parties" or "interested others".
Cooperation and Development in the introductory part of the "The Basic Principles of Corporate Governance"s paper, which reports that the corporate governance is only a part of the wider economic context in which companies operate, and also that it is a key element in improving economic efficiency, growth and investor confidence. An effective system for corporate governance is a necessary prerequisite for more efficient use of resources, better functioning of the market economy and lower capital costs. Corporate governance provides a structure that determines the goals of a company and the means for achieving these goals and tracking results. Traditional financial theory poorly dealt with the issue of corporate governance by recognizing the company as a "black box" that transforms inputs into outputs with the intention of maximizing profits. Modern corporate finance emphasizes the separation of ownership from control during the development of the organizational form of the company, which, due to the imperfections of the market for the product and capital, leaves managers with the possibility to implement other policies with which they achieve personal benefits, in addition to maximizing profits. The problem that emerges during the separation of ownership from control was indicated early in the second half of the eighteenth century by Adam Smith ${ }^{9}$ who stated that directors of the companies are in charge of managing other people's capital, and that they cannot be expected, when managing that capital, to be economical both in a partner society and in owning their own capital. Corporate governance became the subject of extensive public debates in the early 1930s, when Berle and Means ${ }^{10}$ analyzing the growing concentration of economic power in the US corporation, noted that managers control the business operations of large corporations but engage little in the ownership.

On the other hand, they indicated the growing number of corporate action among the parties that have little possibility and interest to supervise and control business operations. Thus the main problem they indicated was the inability of small shareholders to discipline the management. The separation of the owners from the control set a new challenge for the interests of the shareholders. Stiglitz ${ }^{11}$ emphasizes the concentration of financial receivables as one of the most important mechanisms of corporate governance.

8 OECD. (2004). Principles of Corporate Governance. The principles of corporate governance were first published in May 1999 and they are one of the key standards for the international financial stability that is being promoted by the Financial Stability Forum - FSF. The principles were created due to the recognition of importance of corporate governance for the greater confidence of the investors and better economic performance. The principles are constantly being renewed following the latest tendencies in the sphere of corporate governance. The "Principi korporativnog upravljanja" paper in Serbian can be found on this page: http:// www.oecd.org/dataoecd/58/58/34625094.pdf.

9 Smith A. (1776). Inquiry into the Nature and Causes of the Wealth of Nations, p. 264-265.

10 Berle A., \& G. Means. (1932). The Modern Corporation and Private Property. New York: Macmillan.

11 Stiglitz E. J. (2001). Information and the Change in the Paradigm in Economics.Lecture on the Nobel Committee 
Therefore, if the equity capital is concentrated in several investors, each will have enough personal motivation to monitor information and management activities. Ineffective corporate governance results in higher costs of acquiring capital, inefficiency in making investment decisions and slower growth of the firm. Research shows that investors are interested in financial performance indicators, efficiency in management and executive structures, as well as respect for owners' rights and other information on organization and business operations. Adequate legal management of the system, adequate regulations, overcoming the problem of price efficiency of the capital market and protection of elementary proprietary rights are the basic requirements for attracting investors. As stated earlier, corporate governance represents a system of rules and institutions that regulate the control and operations of the corporation by defining the relations between all interested parties in the companies business. Efficient corporate governance is a prerequisite for the economic efficiency and long-term endurance of the company. It reassures the investor that he will make returns on investments in the corporate sector. Although the possible problem of quality corporate governance, due to the separation of ownership from control, was indicated by Adam Smith, in the second half of the eighteenth century, it is considered today that corporate governance is also an underdeveloped academic area with undeveloped theoretical basis and difficulty in gathering quality data during the research of this phenomenon. Numerous empirical researches, with the goal of discovering the cause-effect relationship between the quality of corporate governance and the economic performance of corporations, faced a large number of constraints. And the corporate governance has, in general, become a center of public's interest following great scandals and breakdowns on the financial markets. More intensive research on the impact of the distribution of economic power in corporations on the efficiency of business operations was launched by Adolf Berle and Gardnier Means, in the early 1930s. After empirical and theoretical studies of the corporate governance problems emerged. Recent research on the performance of corporate governance, in terms of business efficiency and the movement of shares in the financial market, has shown that there is a causal link. Quality corporate governance influences the movement of stock prices of companies. Inefficient corporate governance increases the cost of capital and slows down the growth of companies in all models of corporate governance. One of the biggest challenges of today's corporate governance in the world is the convergence of legal systems of corporate governance and good business practices with the strengthened role of international institutions in formulating guidelines in this area. In transitional economies, a good corporate governance system is a prerequisite for attracting direct and portfolio investment and a very important factor of economic restructuring and economic development. The correlation between economic growth and the quality of cor- porate governance has been confirmed in many countries. Corporate governance has become a global topic of public debate due to recognizing the impact on the trends in financial markets, economic growth and employment. In the current transition phase of Serbia, the public interest for the method and efficiency of functioning of internal and external mechanisms of corporate governance is growing. The adoption of the Corporate Governance Code ${ }^{12}$ and the Code of Business Ethics confirms that, with the passing of numerous laws regulating the field of business entity operations, a new transition phase of the development of domestic economy emerged.

\section{TECHNOLOGY INTENSITY INDUSTRIES ACCORDING TO OECD CLASSIFICATION}

Technological intensity of the manufactoring industry (which contains 24 areas of activity) is determined according to the OECD's technical intensity classification, which differentiates four types of activity:

1. High-technology industries: $2 / 24$,

2. Medium High Technology industries: 5/24,

3. Medium Low Technology industries: $6 / 24$, and

4. Low Technology industries: 11/24.

High-technology industries include two activities of the manufacturing industry: production of basic pharmaceutical products and preparations and production of computers, electronic and optical products. These activities comprise about 4.4 percent of the added value of the manufacturing industry and employ 3.3 percent of employees in the domestic manufacturing industry. The average profit earned in high-technology industries is twice as high as the average profit in the manufacturing industry. In the foreign trade exchanges of the goods regarding this industry, a deficit was noted, with an average annual growth of exports in the period 2011-2015 of 5.9 percent (average growth of imports in the same period was 3.9 percent). Indicated activities have potential for conquering new markets, faster growth of exports in the coming years, as well as the potential for engaging in other activities within the production process.

Medium High Technology industries include five activities from the manufacturing industry: production of chemical products, electrical equipment, non-mentioned machines and equipment, motor vehicles, trailers and semi-trailers and the production of other means of transport. These activities account for about 20.5 percent of the value added of the domestic manufacturing industry and employ around 19.5 percent of employees in the manufacturing industry. Average realized net remains at the level of average net return of the manufacturing industry. In the foreign trade exchanges of goods of the mentioned activities a deficit of over 1.6 billion

12 Corporate Governance Code (Official Gazette of the Republic of Serbia, No. 99/2012). 
euros was realized, while the average annual growth of exports was 20.0 percent in the 2011-2015 period (the average growth of imports was 10.9 percent). Export of products of medium high technology activities accounted for 37 percent shares in total exports of manufacturing industry, and 44 percent in imports of manufacturing industry. The indicated activities have potential for conquering new markets, faster growth of exports in the coming years, as well as the potential for engaging in other activities within the production process. The activities where there is a capacity for analyzing the potential of the import substitution are the production of chemicals and chemical products, the production of nonmentioned machines and equipment (general purpose machinery, other general purpose machinery for the industry, agriculture and forestry, metalworking, metallurgy and other branches), production of other means of transport (which includes the production of transport equipment, railway vehicles, locomotives, ships and boats) and the production of motor vehicles as trailers and semi-trailers.

Medium Low Technology industries include six activities of the manufacturing industry (coke and petroleum products production, rubber and plastic products, products from other non-metal minerals, basic metals, metal products, except machinery and equipment and repair and assembly machinery). These activities make a third of the added value of the manufacturing industry and employ about $25 \%$ of the employees in the manufacturing industry. The realized average earnings were by a quarter higher than the average earnings in the manufacturing industry. In the foreign trade exchanges of goods of the mentioned activities, a surplus was realized with the average annual export growth of 4.5 percent in the period 2011-2015 and slower average import growth of 0.4 percent. Export of products of medium low technological activities had a 26.9 percent share in the export of the manufactoring industry, and 22.6 percent in the import of the manufacturing industry. Within the range of the above mentioned activities, the ones that have the highest potential for conquering new markets, faster growth of exports in the coming years, as well as the potential for engagement of other activities within the production process, are the production of rubber and plastic products, the production of metal products except the machines and equipment, but also non-metal minerals and production of base metals.

Low Technology industries include the manufacturing of food, beverages, tobacco products, textiles, clothing, leather and leather goods, wood processing and wood products, cork, straw and wicker, paper and paper products, printing and reproduction of audio and video, furniture production and other manufacturing activities. ${ }^{13}$ Low Technology industries account for 43.9 percent of the total gross added value of the manufacturing industry and employ almost half of the

13 Other manufacturing activities are: manufacture of jewelry, costume jewelery and similar items, repair and assembly of machines and equipment and assembling of industrial machinery. employees in the manufacturing industry. The average profit is lower than the average profit of the manufacturing industry. The highest profit was generated from tobacco products and the smallest from clothing. The production of food products creates the highest added value in this group of productions and at the same time it employs the highest number of registered employees. In the foreign trade exchange of goods of the mentioned activities a surplus was generated in the past period. The export of the low tecnology industry products accounts for 33 percent of total manufacture industry exports and 22 percentage of import. The indicated activities have potential for conquering new markets, faster growth of exports in the coming years, as well as the potential for engaging in other activities within the production process. The surplus is being generated in the production of food, beverages, tobacco products, textiles, clothing, leather and leather goods, wood processing and wood products, cork, straw and wicker, exept for the furniture and the production of furniture. The activities where there is a capacity for analysis of the potential import substitution are the production of paper and paper products, textile industry, printing and reproduction of audio and video.

Regarding the manufacturing sector, the highest share of added value in the total added value of the manufacturing industry relate to low technology industries (44 percent) and medium low technology industries (31 percent). Also, the highest share of employees in low technology industries was registered to be $52 \%$ (employees in the manufacturing industry) and $25 \%$ in medium low technology industries. In the structure of foreign trade we noticed the presence of import of products that objectively have the conditions for the production in the country (certain agricultural products, food industry, paper products, rubber and plastics). Also, Serbia significantly imports automotive parts and other inputs for the vehicle industry, so it is necessary to examine the possibilities of attracting foreign investments in order to enable the local production. The opportunity for increasing domestic production and reducing imports also exists in the chemical industry and paper production. On the other hand, to obtain the sustainable economic growth in the coming period, it is necessary to increase the share of products of higher degree of manufacturing in the structure of exports. In that sense, the use of new technologies, technical and technological innovations, should become prominent in order to create a competitive offer, that could be realized both on the domestic and foreign markets. The importance of "reindustrialization" is apparent and subsequently the Government of the Republic of Serbia has been preparing a new industrial strategy that is in line with EU regulations. For this reason, the attention of the state, as well as the intention of domestic investors, should be directed towards the food industry, the wood and furniture industry, the rubber and plastics industry, as well as the machine industry and equipment industry. Exports of Serbia include raw materials and 
products of lower degree of manufacturing, which is typical for less developed countries and represents a low level of general economic development of Serbia. The most imported products are energy sources and high-tech products, and the export of Serbia is highly concentrated on the EU28, CEFTA and CIS, along with the unused capacities of the import demand of the developing countries outside Europe.

\section{METHODOLOGY}

The research needed for this paper was organized through the case studies of four selected companies, in order to carry out an empirical audit of the basic compliance of small and medium-sized enterprises in the manufacturing industry with key principles of corporate governance.

All four companies selected for case studies are, according to their legal status, limited liability companies having operated on the market for at least 15 years. After the analysis of the latest available financial reports on the SBRA website, it was concluded that they met the conditions for the highest credit worthiness, while according to the NBS data, in the last three years the coercive collection was not recorded. According to the classification of these companies, these companies belong to the $\mathrm{C}$ sector - Manufacturing sector. ${ }^{14}$

\section{RESULTS AND DISCUSSION}

The analysis of the case studies has shown generally good awareness of the management department of selected companies of the idea and importance of corporate governance. A separate analysis of the application of the principles of corporate governance indicates that all four companies incorporated the principle of equal treatment of all owners into their internal rules and clearly defined the staff responsibilities. Except for the company that belongs to the medium high technology industries, the remaining three include the principle of transparency of operations in their internal acts of the company. Also, only the medium high technology company has not adopted procedures that, during the process of making decisions, take into account the interests of the owners and other interested parties in the company's operations (availability of all documents to the shareholders, providing the owner with all relevant data and the like).

Clear definition of the necessary expertise and abilities of the members of the management department, as well as providing them with the continuous training and education, was absent among companies that are ranked as low technology and medium high technology industries. Unlike other analyses, the management structure in an enterprise that is

14 During the selection of companies, the OECD's representation of technology intensity was taken into account, which distinguishes four types of activity: high-technology intensive, medium high technology industries, medium low technology industries and low technology industries. a medium high technology company did not conduct the annual analysis and assessment of the efficiency of its operations and did not consider measures and activities for its improvement.

Management departments in societies, in addition to legally set mandatory procedures, organize other methods in order to conduct better quality analysis of specific problems and identify optimal solutions in companies that belong to high technology and medium low technology industries. Also, the medium low technology company is the only one that has fully established effective mechanisms for accurate and timely reporting of all members on all facts and circumstances that may affect the financial position, business and potential risks to the state of the property of the company.

When it comes to reimbursement for the management structures, the low technology and medium low technology companies employ the principles where the level of remuneration for management structures depends on their contribution to the achievement of results, as well as that the remuneration of management structures consists of a fixed and variable part that depends on their contribution to the realization of financial and non-financial results and business goals of a company, while a medium high technology company somehow employs the principle where the level of remuneration for management structures depends on their contribution to achieving results.

Regardless of the lowest level of application of the principles of corporate governance in the medium high technology company, this company managed to maintain the same level of sales revenue as in the previous year, and the share of goods sales, products and services in the foreign market for total sales revenue rose three times, from 6.5 percent in 2015 to 20.1 percent in 2016.

On the other hand, the medium low technology company fully respects all principles of corporate governance analyzed in the case study. Sales revenue of this company in 2016 was reduced by 8.5 percent compared to 2015 , with a significant change in structure (in 2015 exports accounted for 77.2 percent of sales revenue, whereas goods sales, products and services in the foreign market in total sales revenue in 2016 fell to 42.3 percent).

\section{CONCLUSION}

Case studies of four selected companies have shown a satisfactory level of compliance of small and medium sized enterprises in the manufacturing sector with key principles of corporate governance. The biggest capacity for the application of improvement has been identified with the principles of corporate governance that relate to defining the necessary expertise and competences of the members of the management department and providing continuous training and education for them, as well as the principles related to 
the establishment of effective mechanisms for accurate and timely reporting of facts and circumstances to all members that may affect the financial position, operations and potential risks to the business and the state of the assets of the companies.

\section{LITERATURE}

Berle, A., \& Means, G. (1932). The Modern Corporation and Private Property. New York: Macmillan.

Corporate Governance Code (Official Gazette of the Republic of Serbia, No. 99/2012).

Government of Republic of Serbia. (2017). Economic Reforms Programme for the period 2017-2019.
Organization for Economic Cooperation and Development. (2004). OECD Principles of Corporate Governance

Shileifer A., \& R. W. Vishny. (1996). A Survey of Corporate Governance. National Bureau of Economic Research, Working Paper 5554, Cambridge.

Smith, A. (1776). Inquiry into the Nature and Causes of the Wealth of Nations

Statistical Office of the Republic of Serbia, http://www.stat.gov.rs. Stiglitz, E. J. (2001). Information and the Change in the Paradigm in Economics. Lecture on the Nobel Committee.

The Business Registers Agency. (2017). Report on Economy Performance in Republic of Serbia in 2016.

Tirole, J. (2001). Corporate Governance. Econometrica 69 (1). 